\title{
Early Events Prior to Visual Symptoms in the Apoplectic Form of Grapevine Esca Disease
}

\author{
P. Letousey, F. Baillieul, G. Perrot, F. Rabenoelina, M. Boulay, N. Vaillant-Gaveau, C. Clément, and F. Fontaine
}

First, second, third, fourth, sixth, seventh, and eighth authors: Laboratoire de Stress, Défenses et Reproduction des Plantes, URVVC-SE EA 2069, Université de Reims Champagne-Ardenne, UFR Sciences Exactes et Naturelles, Moulin de la Housse, BP 1039 , 51687 Reims

Cedex 2, France; and fifth author: Moët et Chandon, 6 rue Croix de Bussy, 51200 Epernay, France. Accepted for publication 21 December 2009.

\begin{abstract}
Letousey, P., Baillieul, F., Perrot, G., Rabenoelina, F., Boulay, M., Vaillant-Gaveau, N., Clément, C., and Fontaine, F. 2010. Early events prior to visual symptoms in the apoplectic form of grapevine esca disease. Phytopathology 100:424-431.

Plant infection by pathogens generates various forms of symptoms. Most of them have been described as soon as they become visible, whereas preceding, discrete signs during incubation are poorly or not understood. In Vitis vinifera, esca-related pathogenic fungi inhabit living trunk wood and induce the so-called apoplexy, a sudden wilting of leaves within a few days. To further understand the apoplexy expression, the

apoplectic vines, as revealed by a decrease in gas exchange, changes in chlorophyll fluorescence, and repression of photosynthesis-related genes. In the meantime, expression of defense-related genes was induced and amplified during symptom expression. Water-stress-related genes were specifically investigated because water transport may be impeded by clogging xylem vessels due to esca-causing fungi. Neither of the tested water-stress-related genes was affected in pre-apoplectic grapevine leaves whereas these genes were downregulated in drying leaves. Our results suggest that, during incubation of esca apoplexy, grapevine perceives some signals (likely fungi-originated toxins) and reacts by reducing photosynthesis and triggering defense mechanisms.
\end{abstract} period preceding symptom appearance was investigated by following physiological and molecular markers associated with photosynthetic mechanisms and stress responses. Within the week preceding symptoms, drastic physiological alterations of photosynthesis were registered in pre-
Additional keywords: defense responses, early detection, esca apoplectic form.
In their natural environment, plants are constantly exposed to a variety of pathogens, including bacteria, viruses, and fungi. Phytopathogen infections generate various physiological modifications, including (i) triggering of defense mechanisms (29) and (ii) perturbations of photosynthesis (5).

Plant defense mechanisms following fungal infection are widely documented (33). They include oxidative stress (41), reinforcement of the cell wall (11), phytoalexin production (35), and expression of various pathogenesis-related (PR) proteins (63). In grapevine (Vitis vinifera L.), increased expression of genes encoding chitinases or stimulation of the corresponding enzyme activity has been reported after inoculation of leaves with Botrytis cinerea, Uncinula necator, and Plasmopara viticola $(8,13,16$, $32,37,53)$. Genes encoding enzymes of the phenylpropanoid pathway and stilbene synthase, involved in the synthesis of antimicrobial phenolics, are also induced upon inoculation with B. cinerea $(8,10)$ and Plasmopara viticola $(39,49,61)$.

More recently, it has been shown that the activation of defense mechanisms may be associated with perturbations of primary metabolism, especially photosynthesis $(4,9,55)$, thus affecting plant growth and development. These perturbations are correlated with (i) a reorientation of carbohydrate partitioning for pathogen needs and (ii) the development of chlorotic and necrotic areas in leaves following pathogen infection that leads to a decrease in photosynthetic assimilation $(5,23)$. In grapevine, the effects of

Corresponding author: F. Fontaine;

E-mail address: florence.fontaine@univ-reims.fr

doi:10.1094/PHYTO-100-5-0424

This article is in the public domain and not copyrightable. It may be freely reprinted with customary crediting of the source. The American Phytopathological Society, 2010. fungal infections on the photosynthetic apparatus are poorly documented. To date, only a downregulation of genes involved in photosynthesis has been reported in leaves during Plasmopara viticola infection (50).

Such plant reactions are well understood when the pathogen newly infects a healthy plant. However, little information is currently available about woody plant responses when fungal parasites are chronically present in perennial structures. In this respect, the wood decay disease esca affecting grapevine plants represents an interesting model $(6,64)$. Esca is a complex disease provoked by the presence of at least three fungal species including Phaeomoniella chlamydospora, Phaeoacremonium aleophilum $(20,21,42,46)$, and Fomitiporia mediterranea $(19,26$, $27)$. These pathogens were localized in the woody tissues of perennial organs and in lesser proportions in annual canes $(28,34,42,52)$ but never in leaves where symptoms express. The epidemiology is also special because two forms of symptoms may be distinguished. Chronic symptoms consist of light-green and chlorotic, irregular areas between the veins or along the leaf margin, which gradually spread from the basal to the distal part of the shoot $(17,48)$, whereas a more severe form, so-called apoplexy (22), corresponds to a sudden leaf wilting that leads to death of canes or the whole plant (46) within a few days. Due to the suddenness of the latter, the causes of the apoplectic form of esca are difficult to investigate and, therefore, less documented. However, the speed of visible symptom development suggests that apoplexy results from early events affecting plant physiology linked to the presence of esca fungi in the wood.

To further understand the triggering of the esca apoplectic form in field-grown plants, it was necessary to study first some diseaserelated parameters of plant physiology during the incubation period prior to leaf symptom appearance. For this purpose, 
different aspects of photosynthesis were first investigated, such as fluctuations of photosynthesis-related gene expression, gas exchange, and chlorophyll $a$ fluorescence. In addition, we examined the expression of stress-related genes in pre-apoplectic and drying leaves, with special attention to those involved in water stress responses.

\section{MATERIALS AND METHODS}

Plant material. Experiments were performed on Chardonnay grapevines ( $V$. vinifera) planted in 1986, grafted on 41B rootstock, and trained according to the Chablis method. The experimental site was located in the Moët and Chandon vineyard in Avize (France) with an average annual temperature of $10.8^{\circ} \mathrm{C}$, reaching an average of $19^{\circ} \mathrm{C}$ during apoplexy expression, and $480.7 \mathrm{~mm}$ of annual precipitation. From 2005 to 2007, vines with acute esca symptoms were located and two groups were defined: (i) vines which did not show any esca symptoms, which were visually healthy and considered to be unaffected plants; and (ii) vines which developed apoplexy symptoms and were considered to be diseased plants. In this site, Phaeomoniella chlamydospora and $F$. mediterranea were previously identified in the perennial parts of diseased plants according to the protocol of Dubos (22).

To investigate vines before and during acute esca expression, we chose plants with a high potential to develop the apoplectic form of esca (i.e., $>50 \%$ of the plant had expressed apoplectic form or both esca forms, apoplectic and chronic, during the previous summer). The first apoplectic form appears in July in the Champagne region; therefore, all measurements and sample harvests were performed on leaves twice a week from mid-June to the end of July. Numerous plants were followed in June but only those developing the disease in July were used for the study. At the appearance of foliar symptoms, a retrospective study was performed in order to establish the chronology of the disease, with T0 being day of the apoplexy expression on canes. Thus, gas exchange and chlorophyll $a$ fluorescence were determined on visually healthy leaves 14 (T0-14D) and 7 (T0-7D) days before the expression of apoplexy symptoms on investigated canes. No measurement was performed at T0 because leaves were losing turgidity or wilting. Leaf samples for gene expression analysis were harvested (i) 7 and 2 days before expression of apoplexy symptoms (T0-7D, leaves without symptoms; T0-2D, leaves without symptoms or turgorless leaves) (Fig. 1B and C) and (ii) 1 and 5 days after expression of drying symptoms on investigated canes $(\mathrm{T} 0+1 \mathrm{D}$, turgorless or drying leaves; $\mathrm{T} 0+5 \mathrm{D}$, drying leaves) (Fig. 1E to G).

Gas exchange. Net photosynthesis $\left(\mathrm{P}_{\mathrm{n}}\right)$, stomatal conductance $\left(g_{s}\right)$ and internal leaf $\mathrm{CO}_{2}$ concentration $\left(\mathrm{C}_{\mathrm{i}}\right)$ were determined simultaneously on leaves with a portable infrared gas analysis system (Li-Cor Model 6400, Lincoln, NE). Water use efficiency (WUE) was determined by the ratio of $\left(\mathrm{P}_{\mathrm{n}} / \mathrm{g}_{\mathrm{s}}\right)$ which provides the cost of water for the $\mathrm{CO}_{2}$ assimilation (24). Measurements were conducted between 9:00 a.m. and 11:00 a.m. before the "midday depression" (15) (i.e., the minimal $\mathrm{P}_{\mathrm{n}}$ linked mainly to stomata closure) (57). The infrared gas analysis system was equipped with a clamp-on leaf cuvette that exposed $6 \mathrm{~cm}^{2}$ of leaf area. Environmental conditions during photosynthetic measurements were the following: photosynthetic active radiation $=1,500 \mu \mathrm{mol}$ $\mathrm{m}^{-2} \mathrm{~s}^{-1}$, relative humidity $\approx 30 \%$, and chamber temperature of $20^{\circ} \mathrm{C} . \mathrm{CO}_{2}$ was maintained at a constant level $\left(360 \mu \mathrm{mol}\right.$ liter $\left.^{-1}\right)$
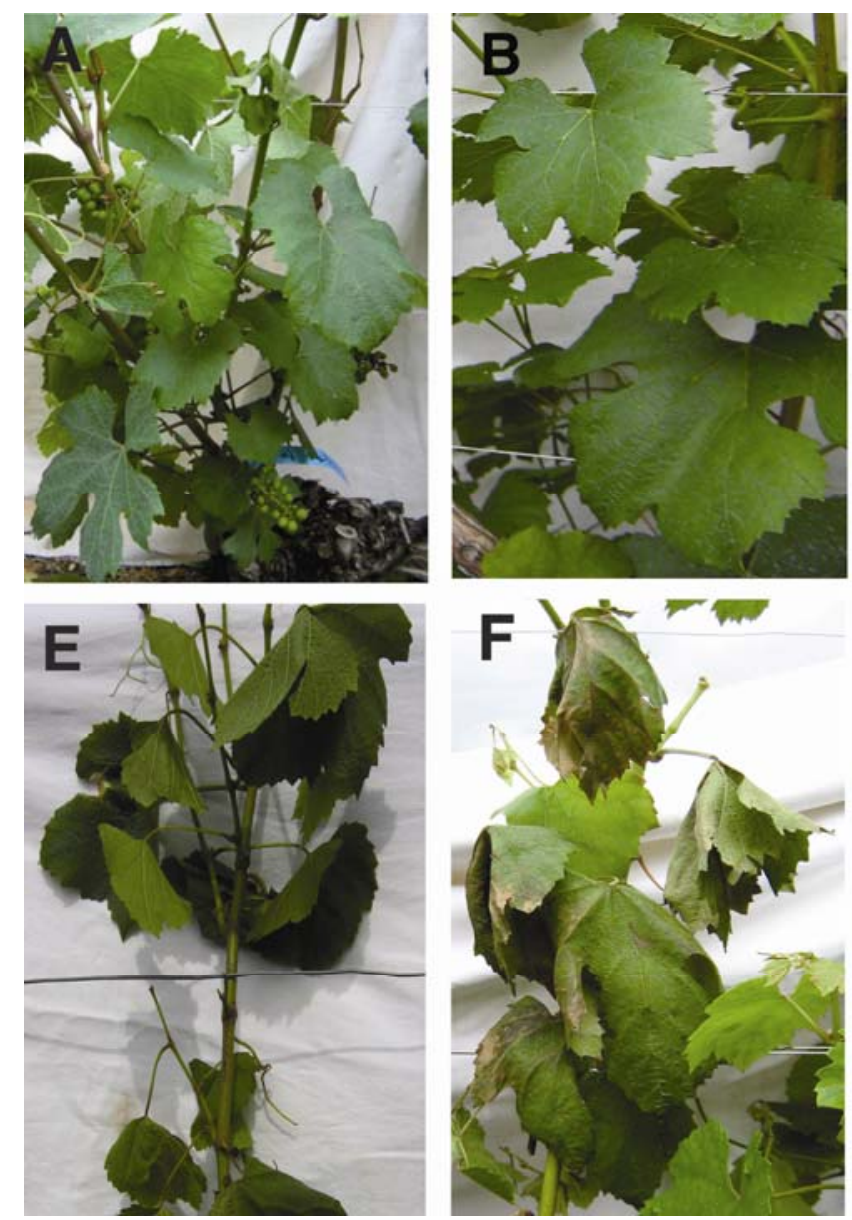
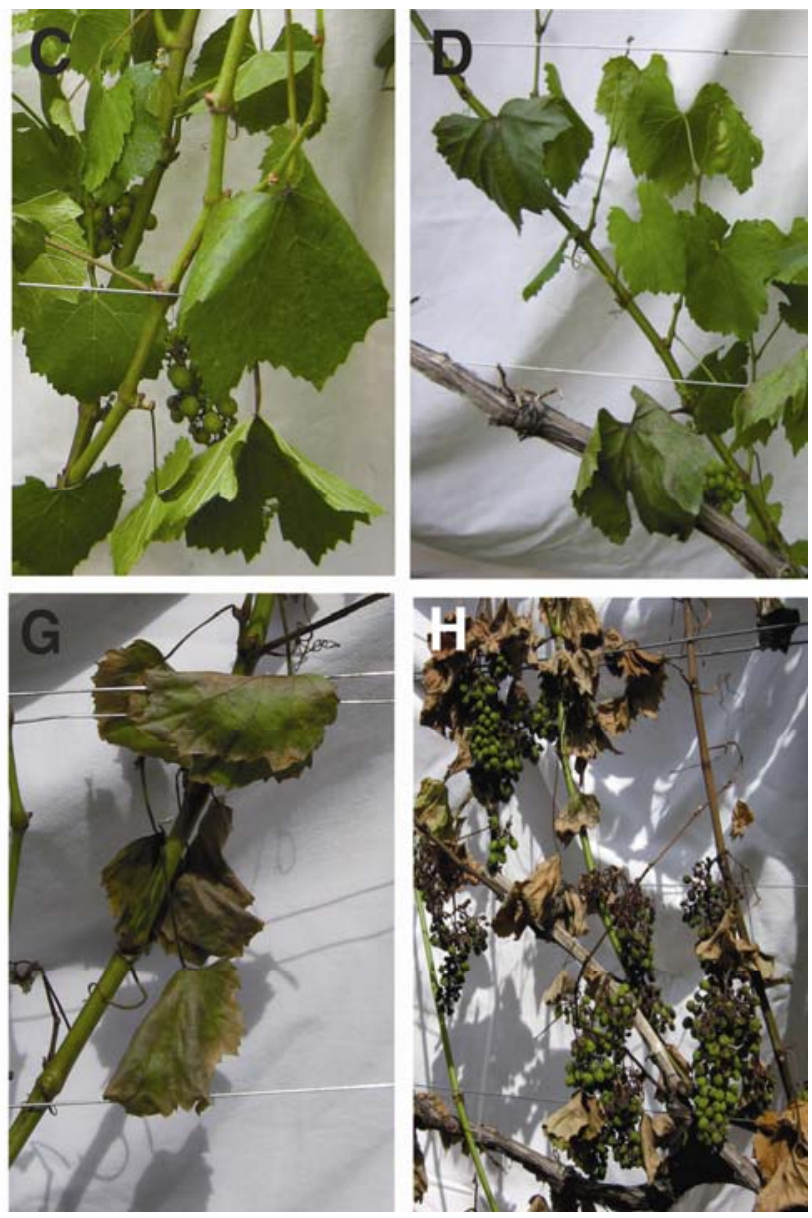

Fig. 1. Symptomatology of the severe form of esca disease (apoplexy) in grapevine leaves. A, Visually healthy control vine. B to $\mathbf{H}$, Apoplexy-affected vine. B, T0-2D: leaves without symptoms. C, T0-2D: turgorless leaves. D, T0: expression of apoplexy symptoms on leaves. E, T0+1D: turgorless leaves. F, T0+1D: drying leaves. G, T0+5D: drying leaves. H, T0+7D: apoplectic vine with dry leaves. 
using a LI-6400-01 $\mathrm{CO}_{2}$ injector with a high-pressure liquid $\mathrm{CO}_{2}$ cartridge source. Gas exchange measurements were repeated three-times on two leaves from five different plants $(n=10)$ from mid-June until apoplexy expression.

Chlorophyll $\boldsymbol{a}$ fluorescence. Chlorophyll fluorescence is a reliable and sensitive marker of plant precocious stress responses $(31,40,45)$. These aspects were previously studied in the chronic form of esca disease $(17,48)$ and showed significant perturbations.

Chlorophyll $a$ fluorescence was evaluated simultaneously with gas exchange measurements using an IMAGING-PAM chlorophyll fluorometer (Walz, Effeltrich, Germany). The measuring system applies an array of blue light-emitting diodes (peak wavelength, $470 \mathrm{~nm}$ ) for saturating light pulses, the frequency of which was adjusted to $10 \mathrm{~Hz}$. Measurements were carried out on a 25-by-34-mm leaf area. During a saturation pulse application $\left(5,000 \mu \mathrm{mol} \mathrm{m} \mathrm{m}^{-2} \mathrm{~s}^{-1}\right)$, the fluorescence yield $(\mathrm{F})$ and the maximum fluorescence yield (Fm') were assessed in leaves exposed to sunlight and an image of the relative quantum yield of PSII was captured. The relative quantum yield of PSII (ФPSII) represented the number of electrons transported by a PSII reaction center per mole of quanta absorbed by PSII. ФPSII was calculated according to Genty et al. (31) following the equation $\Phi$ PSII $=\left(\mathrm{Fm}^{\prime}-\right.$ F)/Fm'. On each image, values of the selected fluorescence parameters were averaged. Chlorophyll fluorescence and gas exchange measurements were carried out sequentially on the same leaves $(n=10)$.

RNA extraction. Leaves were collected in the vineyard before and during the expression of the apoplectic form of esca. They were immediately frozen in liquid nitrogen then stored at $-80^{\circ} \mathrm{C}$. Samples (four pooled leaves from two plants) were ground in liquid nitrogen to a fine powder. Total RNA was isolated from $100 \mathrm{mg}$ of powder using the Plant RNA Purification Reagent (Invitrogen, Cergy Pontoise, France). The RNA pellet was resuspended in $30 \mu \mathrm{l}$ of RNase-free water, then treated with RQ1 DNase enzyme (Promega Corp., Madison, WI) and quantified by absorbance at $260 \mathrm{~nm}$.

Real-time reverse-transcription polymerase chain reaction analysis of gene expression. In all, $150 \mathrm{ng}$ of total RNA were reverse-transcribed using the Verso SYBR 2-step QRT ROX enzyme (ABgene, Surrey, UK) according to the manufacturer's protocol. Polymerase chain reaction (PCR) conditions were as described by Bézier et al. (8). Expression of four photosynthesisrelated genes and eight stress-related genes was tracked by quantitative reverse-transcription (RT)-PCR using the primers indicated in Table 1 . The reactions were carried out in a real-time PCR detector Chromo 4 apparatus (Bio-Rad, Hercules, CA) using the following thermal profile: $15 \mathrm{~s}$ at $95^{\circ} \mathrm{C}$ (denaturation) and $1 \mathrm{~min}$ at $60^{\circ} \mathrm{C}$ (annealing/extension) for 40 cycles. PCR efficiency of the primer sets was calculated by performing real-time PCR on several dilutions. For each experiment, PCR reactions were performed in duplicate and two independent experiments were analyzed. Results correspond to means \pm standard deviation of duplicate reactions of one representative experiment out of two. They were normalized with the EFI- $\alpha$ gene (60) and expressed relative to the control corresponding to a fixed value of 1 . Control samples correspond to leaves collected from symptomless plants. Gene expression was considered as significantly up- or downregulated relative to the $1 \times$ controls when changes in relative expression were $>2 \times$ or $<0.5 \times$, respectively.

Statistical analyses. To determine whether gas exchange and chlorophyll $a$ fluorescence values of esca-affected plants were significantly different from control plants, analysis of variance followed by a Student's $t$ test was used. Differences at $P<0.05$ were considered to be significant.

\section{RESULTS}

The severe form of esca, so-called apoplexy, appeared in midJuly in the Champagne region and was characterized by a sudden wilting of berries and leaves affecting either individual canes or the entire plant (Fig. 1). At 2 and 1 weeks before the appearance of symptoms, leaves were visually similar to those of control plants (Fig. 1A). Two days before the appearance of wilting symptoms (T0-2D), two kinds of leaves were found on preapoplectic canes: leaves without symptoms (Fig. 1B) and leaves that were starting to lose turgidity (Fig. 1C). The day after the expression of wilting symptoms (T0) (Fig. 1D), leaves were flaccid or lax, completely losing turgidity (Fig. 1E), or drying on the cane (Fig. 1F). All leaves continued to dry during the following 5 days (Fig. 1G) and could be considered dead on the cane

TABLE 1 . Genes analyzed by real-time reverse-transcription polymerase chain reaction

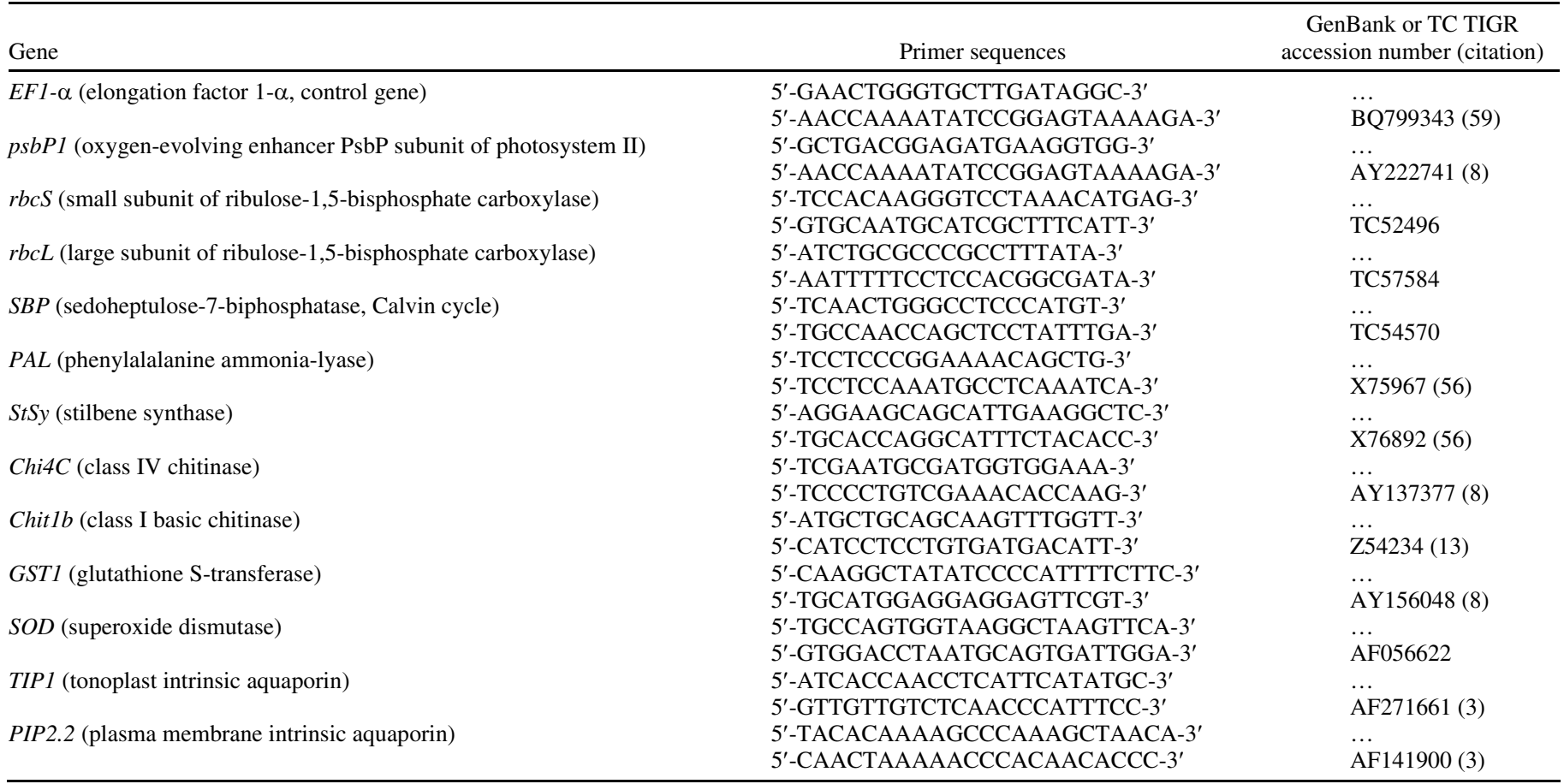


after 7 days $($ Fig. $1 \mathrm{H})$. At this time, it could be noted that any grape clusters present had completely dried.

Gas exchange. No changes were observed in the control over time for any of the measurements (Fig. 2).

There was no significant difference between pre-apoplectic and control leaves at 14 days before apoplexy (T0-14D), whereas a decrease in values was noted in the apoplectic leaves 7 days before wilting (T0-7D, no symptom was visible on leaves and berries) for $\mathrm{P}_{\mathrm{n}}, \mathrm{g}_{\mathrm{s}}$, and WUE measurements that were significantly different than the control $(P<0.05)$. Indeed, $\mathrm{P}_{\mathrm{n}}$ decreased dramatically and was close to zero whereas $P_{n}$ in control leaves remained stable (Fig. 2A). Similarly, $g_{s}$ was significantly reduced by $91 \%$ (Fig. 2B). Associated with low values of both $P_{n}$ and $g_{s}$ 7 days before apoplexy expression, WUE also displayed values significantly lower in pre-apoplectic leaves than in control leaves (Fig. 2C). No measurement was performed at time of wilting (T0) because leaves were losing turgidity or drying.

Only the values for $\mathrm{C}_{\mathrm{i}}$ increased prior to apoplexy, exhibiting a peak at 7 days before wilting (Fig. 2D). The high internal concentration of $\mathrm{CO}_{2}$ in the leaves, correlated with the low values of $\mathrm{P}_{\mathrm{n}}$ and $\mathrm{g}_{\mathrm{s}}$ measured at the same point in time, suggests that nonstomatal factors are involved in the reduction of net photosynthesis.

Chlorophyll $\boldsymbol{a}$ fluorescence. In order to further investigate nonstomatal factors involved in $\mathrm{P}_{\mathrm{n}}$ decrease, ФPSII was followed in parallel. During the assessment period, ФPSII values were constant in control leaves and ranged between $0.7 \pm 0.01$ and $0.66 \pm 0.06$ from T0-14D to T0 (Fig. 3A). No significant difference in ФPSII values was observed between control and preapoplectic leaves 14 days before apoplexy expression (Fig. 3A and B). ФPSII values decreased significantly in leaves (by 27\%) 7 days before apoplexy expression (Fig. 3A). Fluorescent imaging of pre-apoplectic leaves at T0-7D revealed an alteration of photosystem II throughout the mesophyll, as noted by the intense bright green coloration compared with the blue coloration of symptomless control leaves (Fig. 3B). No fluorescence measurement was performed on apoplectic leaves (T0).

Expression pattern of photosynthesis-related genes. Realtime RT-PCR was used to determine changes in photosynthesisrelated gene expression in order to further characterize mechanisms involved in photosynthesis alteration before and during apoplexy expression. At 7 and 2 days before development of apoplexy, all photosynthesis-related genes tested were repressed in asymptomatic or turgorless pre-apoplectic leaves (Fig. 4A). This repression was $\approx 60 \%$ (relative expression of 0.4 ) and reached $80 \%$ (relative expression of 0.2 ) for both $p s b P 1$ and $r b c S$ genes as early as 7 days before apoplexy expression. Similarly, expression of photosynthesis-related genes was strongly repressed as leaf apoplexy progressed (Fig. 4B). The most severe repression was observed 5 days after T0 for all tested genes, reaching $99 \%$ for the $r b c L$ gene.

Expression pattern of stress-related genes. To determine whether stress responses were triggered in apoplexy-affected grapevine, the expression of defense and water-stress-related genes was followed in pre-apoplectic and drying leaves (Figs. 5 and 6). Seven days before apoplexy expression, defense genes
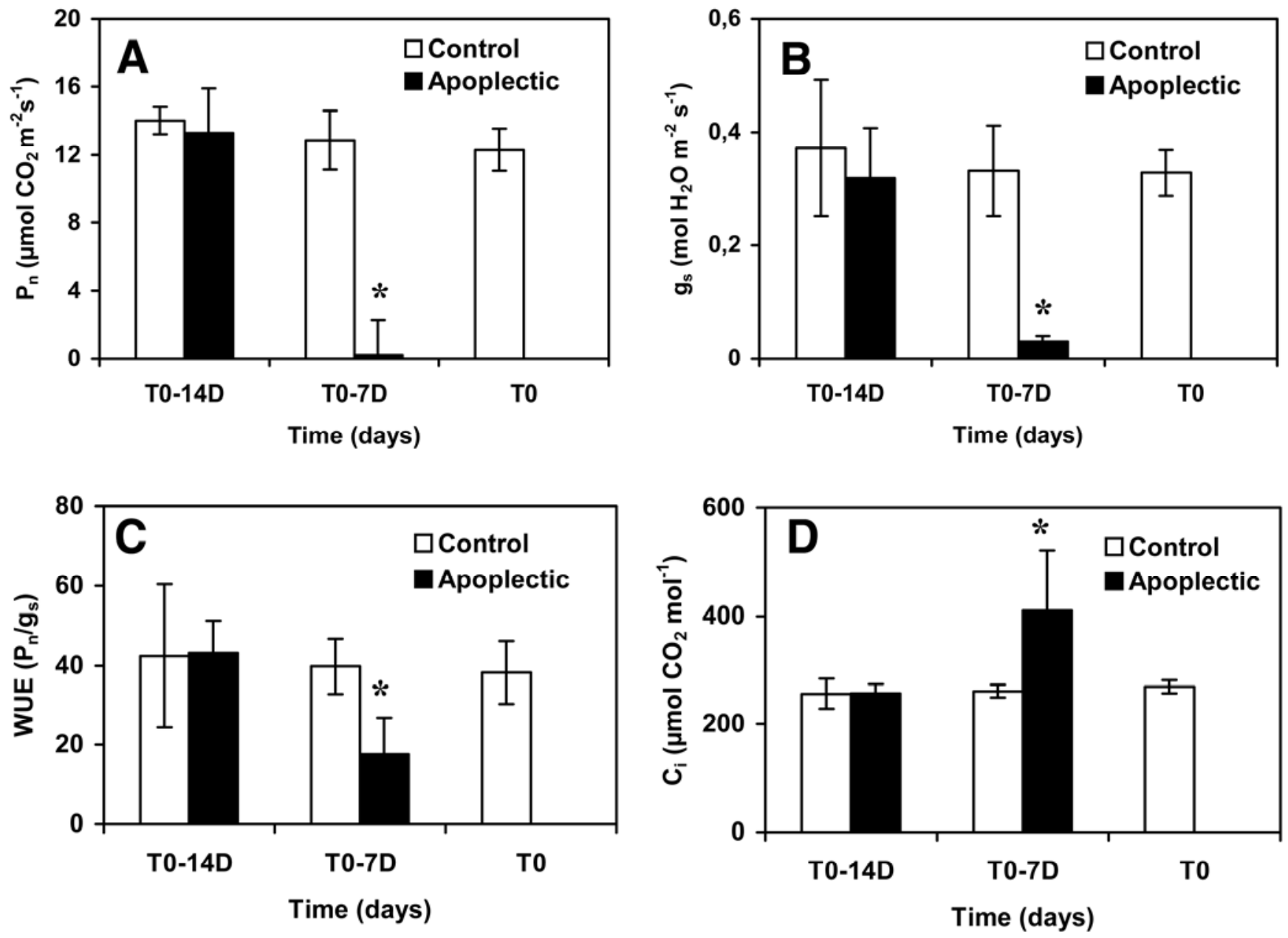

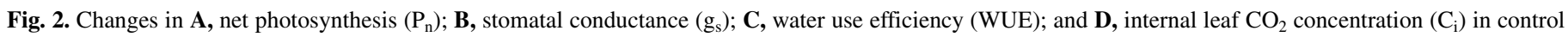

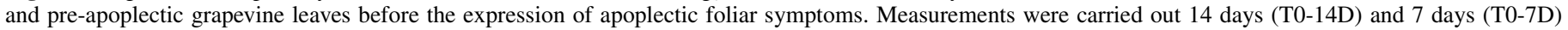

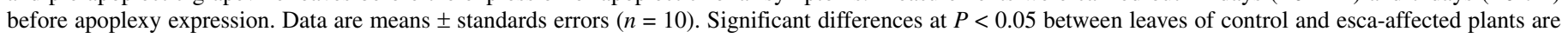
marked by an asterisk. 
encoding enzymes of phenylalanine ammonia-lyase $(P A L)$ and stilbene synthase $(\mathrm{StSy})$ biosynthesis pathways, chitinase (Chi4C), and detoxification enzyme (GST1) were strongly induced in preapoplectic leaves (Fig. 5A). These inductions were maintained 2 days before apoplexy expression, especially PAL, StSy, and GSTI. In the three latter cases, the transcript accumulation rate was at least 35-fold higher in turgorless leaves than in visually healthy control leaves and 2.5-fold higher than in leaves without symptoms. Thus, on a pre-apoplectic plant, the plant as a whole exhibited induced defense responses which were higher in turgorless leaves (i.e., future apoplectic leaves). In contrast, Chi4C exhibited a similar induction in pre-apoplectic leaves at both T0$7 \mathrm{D}$ and $\mathrm{T} 0-2 \mathrm{D}$, with a relative expression close to $\approx 30$ (Fig. 5A). $C h i t 1 b$ expression was slightly induced only in turgorless leaves. Superoxide dismutase $(S O D)$ gene expression decreased by at least $50 \%$ in both types of pre-apoplectic leaves (Fig. 5B). Moreover, aquaporin-encoding genes TIP 1 and PIP2.2 were not significantly affected 7 and 2 days before apoplexy expression (Fig. 5B).

During cane apoplexy, the expression of defense-related genes also showed a strong induction in leaves of apoplectic vines compared with controls (Fig. 6A). In turgorless leaves (T0+1D), the highest gene induction concerned StSy. The expression of $P A L, C h i 4 C$, Chitlb, and GST1 genes was also stimulated but at a lower level. In drying leaves, PAL, StSy, and Chit $1 b$ reached a maximum 1 day after T0. In contrast, expression of Chi4c and
GST1 was more induced after 5 days of apoplexy (90- and 150-fold, respectively) than after 1 day (24-fold) compared with control leaves. This indicates a later induction during apoplexy expression. Considering the three other stress-related genes, the $S O D$ gene was repressed during apoplexy (Fig. 6B), especially at $\mathrm{T} 0+5 \mathrm{D}$, shortly before total cane apoplexy. Regarding water stress, PIP2.2 gene expression was also repressed in drying leaves (Fig. 6B) and down by $99 \% 5$ days after the beginning of cane apoplexy. Furthermore, the other aquaporin gene, TIP1, was weakly repressed only at a late step during apoplexy.

\section{DISCUSSION}

Our study clearly demonstrates a drastic alteration of photosynthetic functions as well as a stimulation of defense responses in apoplexy-affected grapevines several days before any visible symptoms. Moreover, these modifications were amplified as the apoplexy developed, leading to plant dehydration and death.

Before apoplexy expression (T0-7D), photosynthesis was affected as revealed by reduction in gas exchange and chlorophyll $a$ fluorescence, associated with the repression of most photosynthesis-related genes in pre-apoplectic leaves. Photosynthesis alteration was detected as early as 7 days before apoplexy and also during apoplexy expression. This is the first report of early detection of the physiological imbalance in apoplexy-affected grapevine. Moreover, gas exchange analyses indicated that
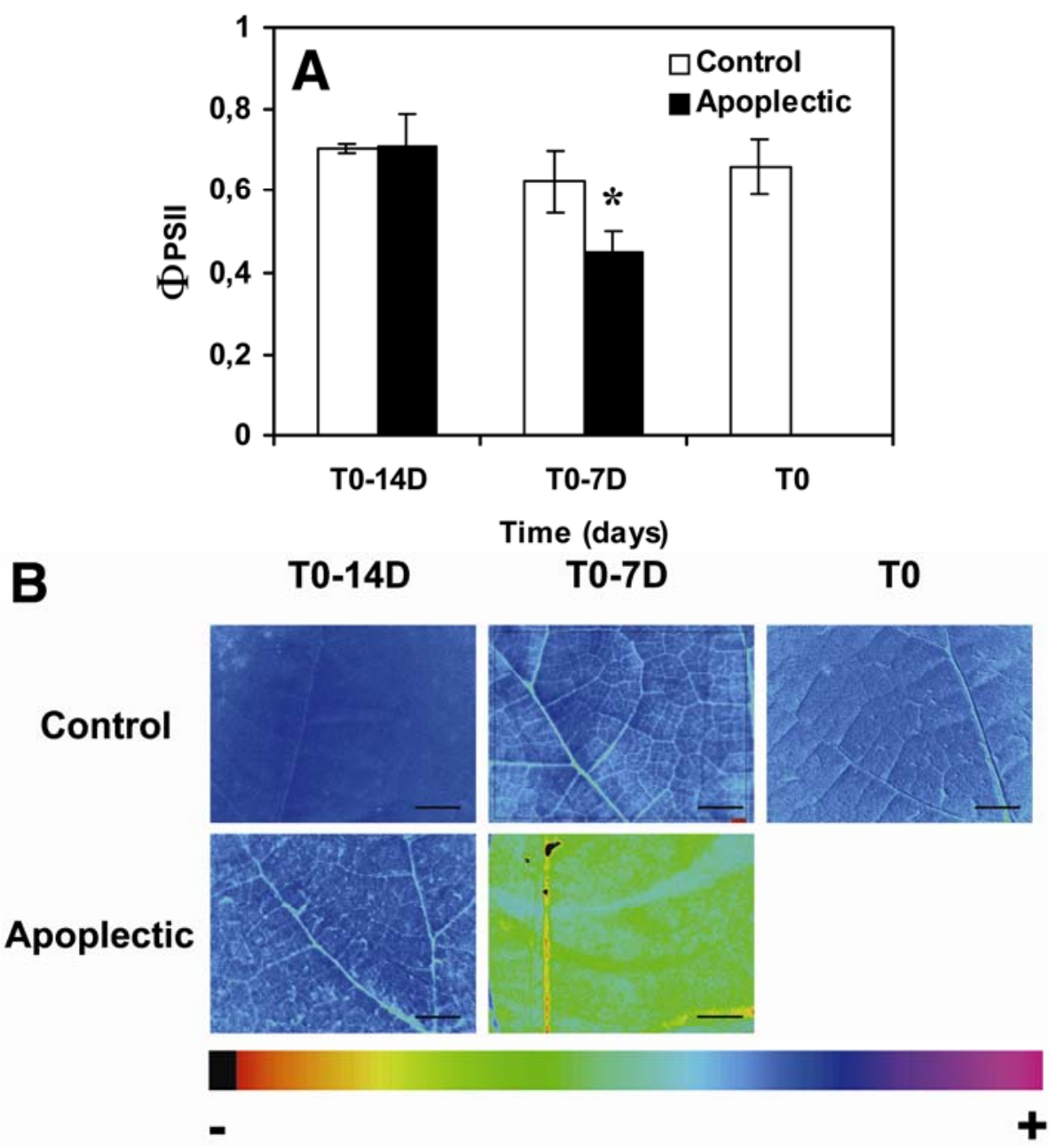

Fig. 3. Changes in chlorophyll $a$ fluorescence in control and pre-apoplectic grapevine leaves before the expression of apoplectic foliar symptoms. A, Relative quantum yield of photosystem II (ФPSII): measurements were performed 14 days (T0-14D) and 7 days (T0-7D) before apoplexy expression. Data are means \pm standards errors $(n=10)$. Significant differences at $P<0.05$ between leaves of control and esca-affected plants are marked by an asterisk. B, Fluorescence imaging: a picture of relative quantum yield of PSII was captured (ФPSII). Data have been mapped to the color palette. The false-color code ranges from black (0.0) to pink (1.0), as shown at the bottom of the images. Scale bars represent $0.5 \mathrm{~cm}$. 
photosynthesis disturbance in pre-apoplectic vines was mainly due to nonstomatal factors because $\mathrm{g}_{\mathrm{s}}$ decreased (i.e., stomata closure) while $\mathrm{C}_{\mathrm{i}}$ increased. Nonstomatal limitation of photosynthesis involves a disruption in metabolic pathways of photosynthesis and has already been reported in response to biotic or abiotic stresses $(47,54)$.

To further assess nonstomatal limitation of $\mathrm{P}_{\mathrm{n}}$, chlorophyll $a$ fluorescence was also analyzed in pre-apoplectic leaves. A weakened PSII function may originate from photosynthesis decrease and PSII function may be assessed by using ФPSII (62). Results showed that DPSII strongly decreased in pre-apoplectic leaves 1 week before disease expression. This reduction in ФPSII may reveal a decrease of the fraction of open reaction centers, causing a downregulation of electron transport (43). Thus, loss in PSII activity observed in pre-apoplectic leaves seems to be involved in the decrease of $\mathrm{P}_{\mathrm{n}}$. Additionally, the expression of four photosynthesis-related genes encoding proteins of PSII ( $p s b P 1$ ), small $(r b c S)$ and large $(r b c L)$ subunits of Rubisco, and sedoheptulose-7-biphosphatase $(S B P)$ was repressed in pre-apoplectic leaves. The repression of the $p s b P l$ expression is in agreement with the reduction of $\Phi$ PSII and confirms an alteration of PSII in pre-apoplectic leaves. Moreover, SBP as well as Rubisco are known to have an essential role in the control of photosynthetic carbon fixation $(36,51)$. Thus, the repression of genes involved in different pathways of the photosynthetic process likely contributes to photosynthesis disruption. Such perturbations of
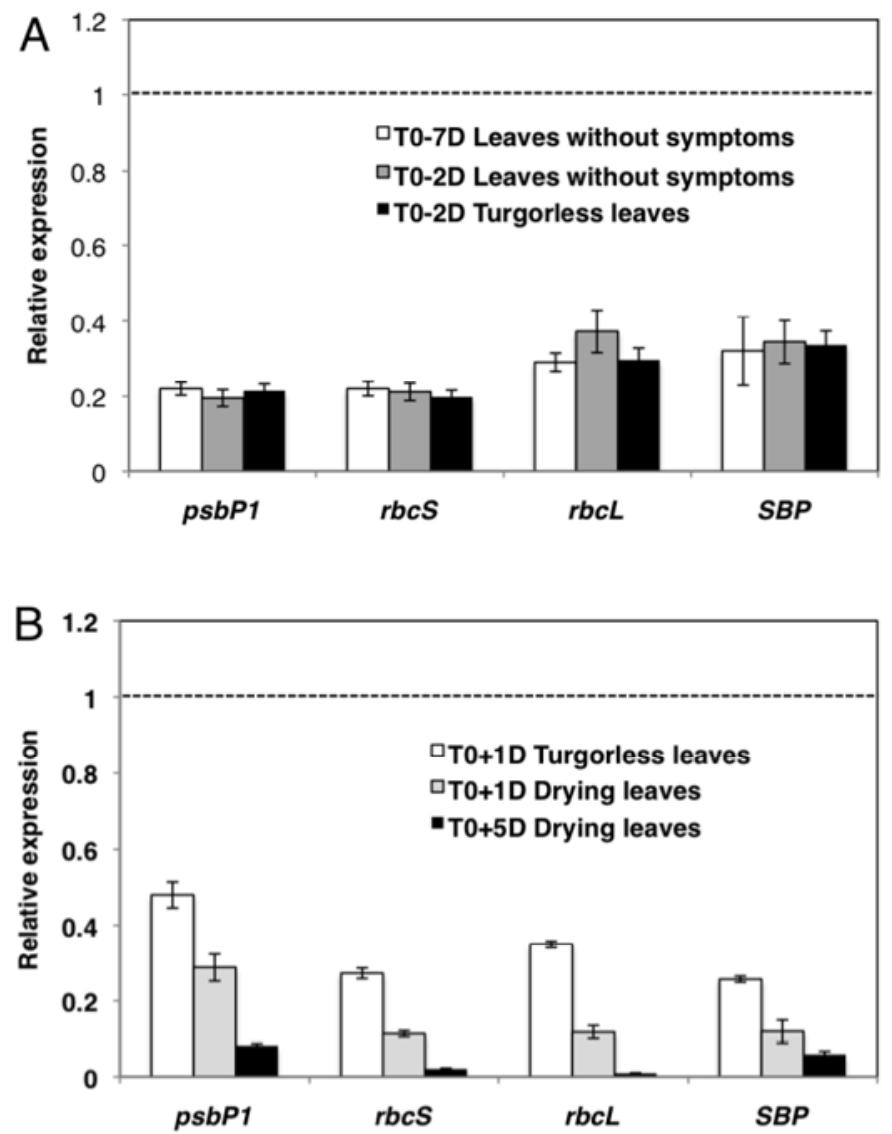

Fig. 4. Expression levels of photosynthesis-related genes in pre-apoplectic and apoplexy-affected grapevine leaves determined by quantitative reverse-transcription polymerase chain reaction experiments. A, Analyses were performed 7 days (T0-7D) and 2 days (T0-2D) before apoplexy expression on leaves with symptoms (turgorless) or without symptoms. B, Analyses were performed 1 day (T0+1D) and 5 days (T0+5D) after apoplexy development on turgorless or drying leaves. The gene expression in the symptomless control leaves was defined as a level of 1.0, as represented by the dotted line on the graphs. Results correspond to means ( \pm standard deviation) of duplicate reactions from one representative experiment out of two. carbohydrate metabolism might be involved in the development of apoplexy symptoms.

The induction of defense reactions is often associated with photosynthesis disturbance observed under stress conditions. For example, in response to pathogen attack, a downregulation of the $r b c S$ gene expression and a simultaneous upregulation of defense genes encoding both PAL and PR proteins have been described $(4,9)$. Thus, we investigated defense responses in leaves before and during apoplexy expression. The expression of most defenserelated genes analyzed in this work is known to be induced in grapevine leaves after exposure to pathogens such as $B$. cinerea, Erysiphe necator, or Plasmopara viticola $(7,8,16,32)$. In agreement with these studies, our results showed that the expression of these genes was activated before apoplexy and then amplified as the disease progressed. Genes encoding PR proteins, PAL, and StSy were strongly overexpressed in pre-apoplectic (seven days prior to symptom expression) and drying leaves. This indicates that grapevine may perceive some signals and react by triggering defense pathways before the appearance of foliar symptoms. PAL and StSy enzymes are related to synthesis of the phytoalexin resveratrol in grapevine (38), and high amounts of resveratrol were found in infected woody tissues (2) and in both leaves and berries of chronic esca-affected vines (14).

Considering Chi $4 \mathrm{C}$ and Chit $1 \mathrm{~b}$, corresponding chitinases might play a role in inhibiting the progression of fungi (18). However, esca-associated fungi were found only in woody tissues of infected grapevines but have never been detected in leaves (34, 42). Moreover, all these defense responses, although especially activated shortly before total leaf apoplexy, were not sufficient to prevent disease injuries. In addition, we analyzed the expression of GST1 and SOD, involved in detoxification processes. GST1 expression was clearly induced whereas $S O D$ was repressed in pre-apoplectic and drying leaves. GST enzymes detoxify endo-
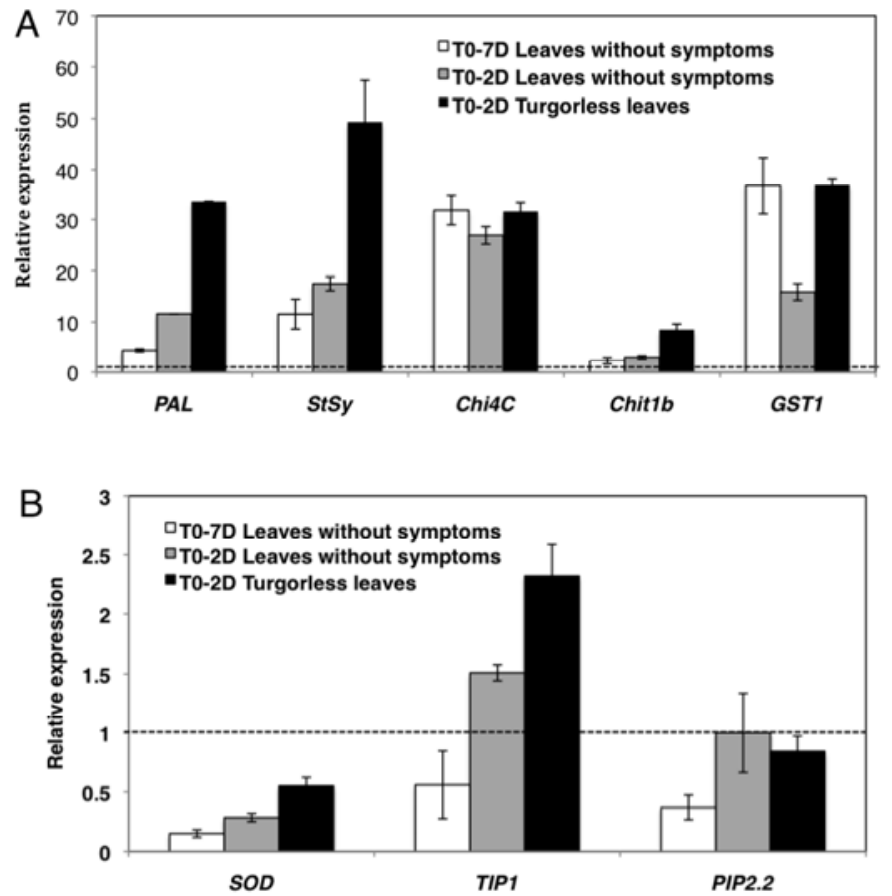

Fig. 5. Expression levels of stress-related genes in leaves without symptoms or turgorless leaves of pre-apoplectic grapevine. Quantitative reverse-transcription polymerase chain reaction analyses were performed 7 days (T0-7D) and 2 days (T0-2D) before expression of apoplexy symptoms. A, Defenserelated genes (PAL, StSy, Chi4C, Chiclb, and GSTI) and $\mathbf{B}$, reactive oxygen species scavenging $(S O D)$ and water-stress-related (TIP1 and PIP2.2) genes. Gene expression in the symptomless control leaves was defined as a level of 1.0 , as represented by the dotted line on the graphs. Results correspond to means ( \pm standard deviation) of duplicate reactions from one representative experiment out of two. 
genous toxic products generated during oxidative stress, such as lipid peroxides (44). GST1 overexpression may suggest the onset of an oxidative stress in severe esca-affected vines. On the other hand, SODs represent the first line of defense against toxic superoxide radicals $\mathrm{O}^{2-}$ generated during oxidative stress (1). Thus, the repression of $S O D$ expression in esca-affected grapevine might indicate a lack of oxidative stress control, which might be lethal for the plant and play a role in sudden wilting of leaves.

Contrary to both photosynthesis disruption and tested defense stimulation described previously, the involvement of water stress in the apoplexy expression seems to be less obvious. Our results showed a significant decrease of $\mathrm{g}_{\mathrm{s}}$ and WUE 1 week before esca expression, suggesting stomata closure in pre-apoplectic leaves. Stomatal closure can function to prevent water stress by preventing excessive water loss. Unexpectedly, the expression of both aquaporin genes TIP1 and PIP2.2 was not affected in preapoplectic grapevine leaves whereas it was repressed in drying leaves after the appearance of symptoms. Galmès et al. (30) showed that aquaporin gene expression was responsive to water stress in Vitis spp. Among the TIPs and PIPS isoforms they studied, TIP1 and PIP2.2 gene expression displayed a rapid downregulation during moderate water stress. This provides useful information to further understand the mechanisms of esca disease. It seems that esca-affected grapevines may perceive a water stress signal only at the latest steps of the disease. In agreement with Christen et al. (17), our results suggest that the appearance of esca foliar symptoms cannot be simply considered as a water transport-deficit-inducing disease but that other physiological mechanisms may be involved. However, more water stress markers have to be investigated to explain stomata closure
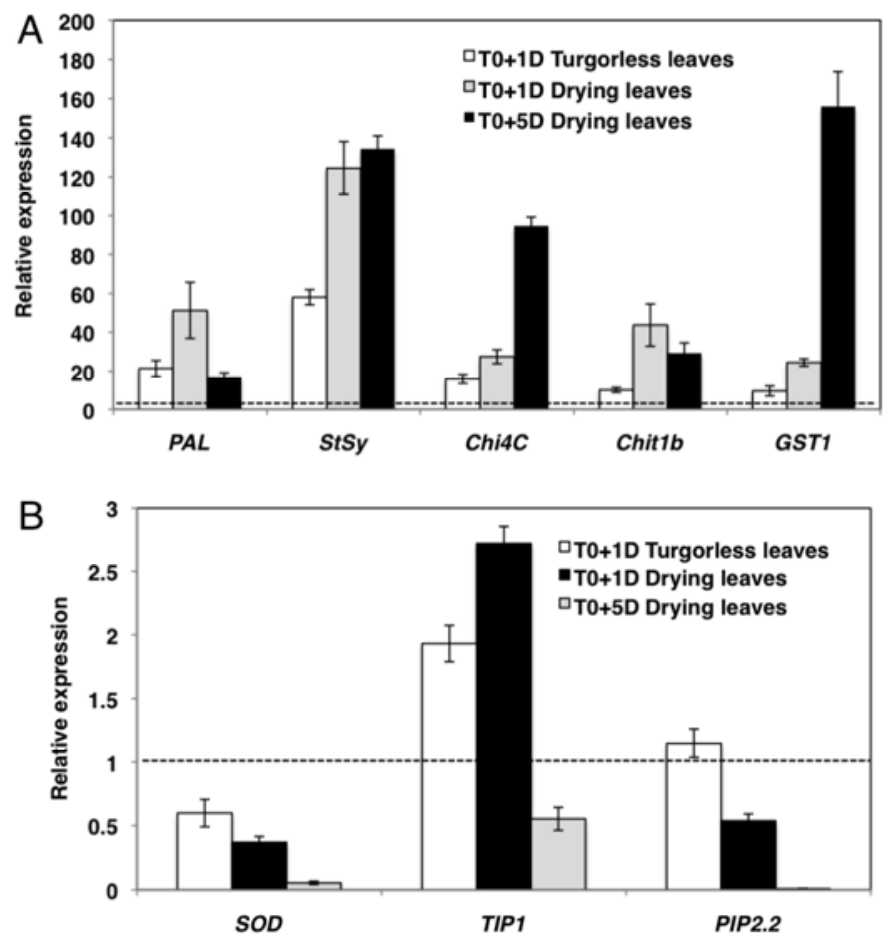

Fig. 6. Expression levels of stress-related genes in turgorless or drying leaves of apoplexy-affected grapevine. Quantitative reverse-transcription polymerase chain reaction analyses were performed after 1 day (T0+1D) and 5 days (T0+5D) of apoplexy symptom development. A, Defense-related genes ( $P A L$, StSy, ChitC, Chiclb, and GSTl) and $\mathbf{B}$, reactive oxygen species scavenging $(S O D)$ and water stress-related (TIP1 and PIP2.2) genes. Gene expression in the symptomless control leaves was defined as a level of 1.0 , as represented by the dotted line on the graphs. Results correspond to means ( \pm standard deviation) of duplicate reactions from one representative experiment out of two. observed before apoplexy expression and involvement of water stress in apoplexy.

Apoplexy-affected grapevine displayed drastic physiological alterations of photosynthesis combined with an activation of stress responses in leaves within at least the 7 days preceding the appearance of visible symptoms. Because the mycelia of esca pathogens were found in neither the herbaceous annual shoots nor the foliage of infected plants, it was hypothesized that leaf and berry symptoms are actually caused by toxic compounds (12, 25,58). These molecules may be produced by esca-associated fungi in the discolored woody tissues of the trunk and then translocated to leaves via the transpiration stream (46). Our findings show an induction of defense responses, including those involved in detoxification processes in pre-apoplectic leaves, which points out the importance of the toxin hypothesis in leaf symptom development. Thus, the involvement of fungal toxins in the triggering of esca disease must be investigated in order to identify the causes of esca symptom expression. In addition, early detection using physiological parameters by easy-to-use and nondestructive methods could be useful for precocious diagnostics and control interventions. Thus, preventive cures to control esca disease could be tested in accordance with the early perturbations.

\section{ACKNOWLEDGMENTS}

We thank Europôl'Agro for financial support that made this study possible, H. Yean for technical assistance in setting up the field experiments, and S. Ricord for English corrections.

\section{LITERATURE CITED}

1. Alscher, R. G., Erturk, N., and Heath, L. S. 2002. Role of superoxide dismutases (SODs) in controlling oxidative stress in plants. J. Exp. Bot. 53:1331-1341.

2. Amalfitano, C., Evidente, A., Surico, G., Tegli, S., Bertelli, E., and Mugnai, L. 2000. Phenols and stilbene polyphenols in the wood of escadiseased grapevine. Phytopathol. Mediterr. 39:178-183.

3. Baiges, I., Schäffner, A. R., and Mas, A. 2001. Eight cDNA encoding putative aquaporins in Vitis hybrid Richter-110 and their differential expression. J. Exp. Bot. 52:949-1951.

4. Berger, S., Papadopoulos, M., Schreiber, U., Kaiser, W., and Roitsch, T. 2004. Complex regulation of gene expression, photosynthesis and sugar levels by pathogen infection in tomato. Physiol. Plant.122:419-428.

5. Berger, S., Sinha, A. K., and Roitsch, T. 2007. Plant physiology meets phytopathology: Plant primary metabolism and plant-pathogen interactions. J. Exp. Bot. 58:4019-4026.

6. Bertsch, C., Larignon, P., Farine, S., Clément, C., and Fontaine, F. 2009. Grapevine trunk diseases: A new health crisis in the wine-growing industry? Science 324:721.

7. Bézier, A. 2003. Caractérisation de gènes de défense exprimés par la vigne en réponse à l'infection par Botrytis cinerea par la technique de differential display RT-PCR. Doctoral thesis, University of ChampagneArdenne, Reims, France.

8. Bézier, A., Lambert, B., and Baillieul, F. 2002. Study of defense-related gene expression in grapevine leaves and berries infected with Botrytis cinerea. Eur. J. Plant Pathol. 108:111-120.

9. Bonfig, K. B., Schreiber, U., Gabler, A., and Roitsch, T. 2006. Infection with virulent and avirulent $P$. syringae strains differentially affects photosynthesis and sink metabolism in Arabidopsis leaves. Planta 225:112 .

10. Borie, B., Jeandet, P., Parize, A., Bessis, R., and Adrian, M. 2004. Resveratrol and stilbene synthase mRNA production in grapevine leaves treated with biotic and abiotic phytoalexin elicitors. Am. J. Enol. Viticult. 55:60-64.

11. Brisson, L. F., Tenhaken, R., and Lamb, C. 1994. Function of oxidative cross-linking of cell wall structural proteins in plant disease resistance. Plant Cell 6:1703-1712.

12. Bruno, G., Sparapano, L., and Graniti, A. 2007. Effects of three escaassociated fungi on Vitis vinifera L.: IV. Diffusion through the xylem of metabolites produced by two thracheiphilous fungi in the woody tissue of grapevine leads to esca-like symptoms on leaves and berries. Physiol. Mol. Plant Pathol. 71:106-124.

13. Busam, G., Kassemeyer, H. H., and Matern, U. 1997. Differential expression of chitinases in Vitis vinifera L. responding to systemic acquired resistance activators or fungal challenge. Plant Physiol. 115:1029-1038. 
14. Calzarano, F., D’Agostino, V., and Del Carlo, M. 2008. Trans-resveratrol extraction from grapevine: Application to berries and leaves from vines affected by esca proper. Anal. Lett. 41:649-661.

15. Chaumont, M., Morot-Gaudry, J. F., and Foyer, C. 1994. Seasonal and diurnal changes in photosynthesis and carbon partitioning in Vitis vinifera leaves in vines with and without fruit. J. Exp. Bot. 45:1235-1243.

16. Chong, J., Le Henanff, G., Bertsch, C., and Walter, B. 2008. Identification, expression analysis and characterization of defense and signaling genes in Vitis vinifera. Plant Physiol. Biochem. 46:469-481.

17. Christen, D., Schönmann, S., Jermini, M., Strasser, R. J., and Défago, G. 2007. Characterization and early detection of grapevine (Vitis vinifera) stress responses to esca disease by in situ chlorophyll fluorescence and comparison with drought stress. Environ. Exp. Bot. 60:504-514.

18. Collinge, D. B., Kragh, K. M., Mikkelsen, J. D., Nielsen, K. K., Rasmussen, U., and Vad, K. 1993. Plant chitinases. Plant J. 3:31-40.

19. Cortesi, P., Fischer, M., and Milgroom, M. G. 2000. Identification and spread of Fomitiporia punctata associated with wood decay of grapevine showing symptoms of esca. Phytopathology 90:967-972.

20. Crous, P. W., and Gams, W. 2000. Phaeomoniella chlamydospora gen. et comb. Nov., a causal organism of Petri grapevine decline and esca. Phytopathol. Mediterr. 39:112-118.

21. Crous, P. W., Gams, W., Wingfield, M. J., and Van Wyk, P. S. 1996. Phaeoacremonium gen. nov. associated with wilt and decline disease of woody hosts and human infections. Mycologia 88:786-796.

22. Dubos, B. 2002. Le syndrome de l'esca. Pages 127-136 in: Maladies Cryptogamiques de la Vigne. Féret, Bordeaux, France.

23. Ehness, R., Ecker, M., Godt, D. E., and Roitsch, T. 1997. Glucose and stress independently regulate source and sink metabolism and defense mechanisms via signal transduction pathway involving proteins phosphorylation. Plant Cell 9:1825-1841.

24. Epron, D., and Dreyer, E. 1993. Long-term effects of drought on photosynthesis of adult oak trees (Quercus petraea (Matt.) Liebl. and Quercus robur L.) in a natural stand. New Phytol. 125:381-389.

25. Evidente, A. L., Sparapano, A., Andofi, A., and Bruno, G. 2000. Two napthalenone pentaketides from liquid cultures of Phaeoacremonium aleophilum, a fungus associated with esca of grapevine. Phytopathol. Mediterr. 39:162-168.

26. Fischer, M. 2002. A new wood-decaying basidiomycete species associated with esca of grapevine: Fomitiporia mediterranea (Hymenochaetales). Mycol. Prog. 1:299-313.

27. Fischer, M., and Kassemeyer, H. H. 2003. Fungi associated with esca disease of grapevine in Germany. Vitis 42:109-116.

28. Fourié, P. H., and Halleen, F. 2002. Investigation on the occurrence of Phaeomoniella chlamydospora in canes rootstock mother vines. Australas. Plant Pathol. 31:425-427.

29. Fujita, M., Fujita, Y., Noutoshi, Y., Takahashi, F., Narusaka, Y., Yamaguchi-Shinozaki, K., and Shinozaki, K. 2006. Crosstalk between abiotic and biotic stress responses: A current view from the points of convergence in the stress signalling networks. Curr. Opin. Plant Biol. 9:436-442.

30. Galmès, J., Pou, A., Mar Alsina, M., Tomas, M., Medrano, H., and Flexas, J. 2007. Aquaporin expression in response to different water stress intensities and recovery in Richter-110 (Vitis sp.): Relationship with ecophysiological status. Planta 226:671-681

31. Genty, B., Briantais, J. M., and Baker, N. R. 1989. The relationship between quantum yield of photosynthetic electron transport and quenching of chlorophyll fluorescence. Biochim. Biophys. Acta 990:8792.

32. Giannakis, C., Bucheli, C. S., Skene, K. G. M., Robinson, S. P., and Scott, S. N. 1998. Chitinase and $\beta$-1,3-glucanase in grapevine leaves: A possible defense against powdery mildew infection. Aust. J. Grape Wine Res. 4:14-22.

33. Glazebrook, J. 2005. Contrasting mechanisms of defense against biotrophic and necrotrophic pathogens. Annu. Rev. Phytopathol. 43:205-227.

34. Graniti, A., Giuseppe, S., and Mugnai, L. 2000. Esca of grapevine: A disease complex or a complex of diseases? Phytopathol. Mediterr. 39:1620 .

35. Harmmerschmidt, R. 1999. Phytoalexins: What we learned after 60 years? Annu. Rev. Phytopathol. 37:285-306.

36. Harrison, E. P., Olcer, H., Lloyd, J. C., Long, S. P., and Raines, C. A. 2001. Small decreases in SBPase cause a linear decline in the apparent RuBP regeneration rate, but do not affect Rubisco carboxylation capacity. J. Exp. Bot. 52:1779-1784.

37. Jacobs, A. K., Dry, I. B., and Robinson, S. P. 1999. Induction of different pathogenesis-related cDNAs in grapevine infected with powdery mildew and treated with ethephon. Plant Pathol. 48:325-336.

38. Jeandet, P., Douillet-Breuil, A. C., Bessis, R., Debord, S., Sbaghi, M., and Adrian, M. 2002. Phytoalexins from the Vitaceae: Biosynthesis, phytoalexin gene expression in transgenic plants, antifungal activity, and metabolism. J. Agric. Food Chem. 50:2731-2741.
39. Kortekamp, A. 2006. Expression analysis of defense-related genes in grapevine leaves after inoculation with a host and a non-host pathogen. Plant Physiol. Biochem. 44:58-67.

40. Krause, G. H., and Weis, E. 1991. Chlorophyll fluorescence and photosynthesis: The basics. Annu. Rev. Plant Physiol. Plant Mol. Biol. 42:313349.

41. Lamb, C, and Dixon, R. A. 1997. The oxidative burst in plant disease. Annu. Rev. Plant Physiol. Plant Mol. Biol. 48:251-275.

42. Larignon, P., and Dubos, B. 1997. Fungi associated with esca disease in grapevine. Eur. J. Plant Pathol. 103:147-157.

43. Lu, C., and Zhang, J. 2000. Photosynthetic $\mathrm{CO}_{2}$ assimilation, chlorophyll fluorescence and photoinhibition as affected by nitrogen deficiency in maize plants. Plant Sci. 151:135-143.

44. Marrs, K. A. 1996. The functions and regulation of glutathione S-transferases in plants. Annu. Rev. Plant Physiol. Plant Mol. Biol. 47:127-158.

45. Maxwell, K., and Johnson, G. N. 2000. Chlorophyll fluorescence: A practical guide. J. Exp. Bot. 51:659-668

46. Mugnai, L., Graniti, A., and Surico, G. 1999. Esca (Black Measles) and brown wood-streaking: Two old and elusive diseases of grapevines. Plant Dis. 83:404-418.

47. Petit, A. N., Fontaine, F., Clément, C., and Vaillant-Gaveau, N. 2008. Photosynthesis limitations of grapevine after treatment with the fungicide fludioxonil. J. Agric. Food Chem. 56:6761-6767.

48. Petit, A. N., Vaillant, N., Boulay, M., Clément, C., and Fontaine, F. 2006 Alteration of photosynthesis in grapevines affected by esca. Phytopathology 96:1060-1066.

49. Pezet, R., Perret, C., Jean-Denis, J. B., Tabacchi, R., Gindro, K., and Viret, O. 2003. $\delta$-Viniferin, a resveratrol dehydrodimer: One of the major stilbenes synthesized by stressed grapevine leaves. J. Agric. Food Chem. 51:5488-5492.

50. Polesani, M., Desario, F., Ferrarini, A., Zamboni, A., Pezzotti, M., Kortekamp, A., and Polverari, A. 2008. cDNA-AFLP analysis of plant and pathogen genes expressed in grapevine infected with Plasmopara viticola. BMC Genomics 9:142-166.

51. Raines C. A. 2003. The Calvin cycle revisited. Photosynth. Res. 75:1-10.

52. Retief, E., McLeod, A., and Fourie P. H. 2006. Potential inoculum sources of Phaeoacremonium chlamydospora in South African grapevine nurseries. Eur. J. Plant Pathol. 115:331-339.

53. Robert, N., Roche, K., Lebeau, Y., Breda, C., Boulay, M., Esnault, R., and Buffard, D. 2002. Expression of grapevine chitinase genes in berries and leaves infected by fungal or bacterial pathogens. Plant Sci. 162:389-400.

54. Saeed, I. A. M., MacGuidwin, A. E., Rouse, D. I., and Sharkey, T. D. 1999. Limitation to photosynthesis in Pratylenchus penetrans- and Verticillium dahliae-infected potato. Crop Sci. 39:1340-1346.

55. Scharte, J., Schön, H., and Weis, E. 2005. Photosynthesis and carbohydrate metabolism in tobacco leaves during an incompatible interaction with Phytophthora nicotianae. Plant Cell Environ. 28:1421-1435.

56. Sparvoli, F., Martin, C., Scienza, A., Gavazzi, G., and Tonelli, C. 1994. Cloning and molecular analysis of structural genes involved in flavonoid and stilbene biosynthesis in grape (Vitis vinifera L.). Plant Mol. Biol. 24:243-755.

57. Stoev, K., and Slavtcheva, T. 1982. La photosynthèse nette chez la vigne (V. vinifera L.) et les facteurs écologiques. Connaiss. Vigne Vin 16:171185 .

58. Tabacchi, R., Fkeyrat, A., Poliart, C., and Dubin, G. M. 2000. Phytotoxins from fungi of esca of grapevine. Phytopathol. Mediterr. 39:156-161.

59. Terrier, N., Ageorges, A., Abbal, P., and Romieu, C. 2001. Generation of ESTs from grape berry at various developmental stages. J. Plant Physiol. 158:1575-1583.

60. Terrier, N., Glissant, D., Grimplet, J., Barrieu, F., Abbal, P., Couture, C., Ageorges, A., Atanassova, R., Léon, C., Renaudin, J. P., Dédaldéchamp, F., Romieu, C., Delrot, S., and Hamdi, S. 2005. Isogene specific oligo arrays reveal multifaceted changes in gene expression during grape berry (Vitis vinifera L.) development. Planta 222:832-847.

61. Trouvelot, S., Varnier, A. L., Allègre, M., Mercier, L., Baillieul, F., Arnould, C., Gianinazzi-Pearson, V., Klarzynski, O., Joubert, J. M., Pugin, A., and Daire, X. 2008 A $\beta-1,3$ glucan sulfate induces resistance in grapevine against Plasmopara viticola through priming of defense responses, including HR-like cell death. Mol. Plant-Microbe Interact. $21: 232-243$

62. van Kooten, O., and Snel, J. F. H. 1990. The use of chlorophyll fluorescence nomenclature in plant stress physiology. Photosynth. Res. 25:147150.

63. Van Loon, L. C., and Van Strien, E. A. 1999. The families of pathogenesis-related proteins, their activities, and comparative analysis of PR-1 type proteins. Physiol. Mol. Plant Pathol. 55:85-97.

64. Wagschal, I., Abou-Mansour, E., Petit, A. N., Clément, C., and Fontaine, F. 2008. Wood diseases of grapevine: A review on Eutypa dieback and esca. Pages 367-391 in: Plant-Microbe Interactions. E. Ait Barka and C. Clément, eds. Research Signpost, Kerala, India. 